\title{
RSRNAS 2 Design Decision Estimation
}

\author{
Orazkhan Karlihanovich Karlihanov, Mahsut Ahmetjanovich Balgerey, \\ Assela Muratbecovna Ongarbayeva \\ Kazakh Research Institute of Water Management, Taraz, Kazakhstan \\ Email: orazkhantaraz@yandex.kz, asela.on@gmail.com, kiwr-t@mail.ru
}

Received 12 September 2014; revised 8 October 2014; accepted 5 November 2014

Copyright (C) 2014 by authors and Scientific Research Publishing Inc.

This work is licensed under the Creative Commons Attribution International License (CC BY). http://creativecommons.org/licenses/by/4.0/

c) (†) Open Access

\begin{abstract}
Kazakh Research Institute of Water as a leading research organization on water problems works on scientific reasoning of water problems solution in the republic. The institute activity is a multifaceted and an integral part of its activity is, particularly, a system research, analysis and evaluation of developed projects of hydro economic rebuilding in the river basins. One of such significant documents of the last time is the project of regulation of the Syr-Darya River and the north-end of the Aral Sea. The experts of the institute took part in the state expertise of this project and estimated its significance for ecological revival of the region.
\end{abstract}

\section{Keywords}

Aral Sea, Syr-Darya Rivers, Reservoir, Flow, Flood

\section{Introduction}

The second phase of the regulation of the Syr-Darya River and the north-end of the Aral Sea (RSRNAS 2) is the part of a large international program on ecological rehabilitation of the Aral Sea basin, prepared by the World Bank together with the environmental protection program of the United Nations Organization. The principal conditions of the project are: stabilization of the environment in the water area of the existed sea, reconstruction of the ecological catastrophe zone of the Aral Sea and complex control of water sources.

The RSRNAS 2 project is the continuation of the realized RSRNAS 1 project and is to solve the following problems: ecological rebirth of the region; improvement of water application efficiency in downstream of the river; improvement of organizational control capabilities in water sources on local, national and interstate transborder levels. The project zone includes Kazakhstan part of the Syr-Darya river basin and the Northern Aral Sea (NAS).

The project is a part of the National ecological operation plan and the Concept of sustained development of the republic of Kazakhstan for 2007 - 2024, and is certified by the government of the republic of Kazakhstan.

The International consortium of the companies "Euro consult Mott MacDonald”, "Jacobs Babtie”, "Danish 
Hydraulic Institute”, "Kazgiprovodhoz Institute”, that designed the RSRNAS 2 scheme for the first time, have executed a great spectrum of researches in analysis of extremely set off condition of hydro economic and ecological situation in the Syr-Darya river basin and the Aral Sea and they have also suggested the action plan for solving the accumulated complicated problems [1].

\section{Materials and Methods}

\subsection{Estimation of Accepted Technical Solutions}

In a modern geopolitical situation in Central Asia the necessity of the existing system of river flow regulation revision and safety measures provision of the region, exposed to waterflooding below the Shardara dam have occurred. First of all it is connected with the change of the of the independent States in the region requirements for water sources of the Syr-Darya river in the context of orientation on their own national interests and programs of their development.

The centralized flow regulation system and the accident prevention system of the region from waterflooding while controlling the stream flow of the Syr-Darya River using all regulating reservoirs of the basin, that pre-existed till 1992 year was completely changed. These changes in nowadays result to regular spring emergency conditions on the territory of Kazakhstan and to winter difficulties in the context of situation of basic regulating reservoirs on territories of other states.

The operating regime of the key element of the Naryn-Syr-Darya cascade-the Toktogul waterworks facility from 1992 changed from irrigative to energy that satisfies national interests of Kyrgyzstan. As a result the winter evacuation of reservoir capacity began and this caused the beginning of crisis situations on the systems of middle reach and downstream of the Syr-Darya river. This predetermined the engineering of given project and necessity of its estimation [2].

The information system of water-resources management (ISWRM) in Kazakhstan part of the Syr-Darya river basin has a great value in the project.

\subsection{The Information System of Water-Resources Management}

The Information System of Water-Resources Management was designed on the basis of the existing water sources database, which was developed for the Water Sources Committee of the Ministry of Agriculture of the republic of Kazakhstan under the EDIKO project, financed by the TACIS and developed in 2005.

This system includes two components:

- Geographic information systems (GIS);

- Microsoft Access database.

For the Syr-Darya river basin in GIS there are made:

- Separated layers in the ArcGIS program: water catchment of the Syr-Darya river basin and the Syr-Darya river itself, hydrological stations on the river, water-storage reservoirs, basic constructions on the river, irrigative and drainage canals, swamp area, lakes and NAS;

- Water resources database systematization: monthly data about rates throughout all hydrological stations on the river (for the period from 1912 to 2005), characteristics of main water-storage reservoirs (surface area, cubature) that are situated apically, carrying capacity of the river, more detailed data about water withdrawal from river by types of water consumption, irrigative regeneration flow, waste and water loss, electricity production etc.

The database of the RSRNAS 2 project is sizably widened and it includes:

- Additional GIS layers that encircle heads of water catchment of the Syr-Darya river basin that are situated upper Shardara, with additionally included: water-storage reservoirs (Toktogul, Andizhan, Kairakkum, Charvak and Arnasai), hydrological stations in the river headwaters, irrigative constructions, hydroelectric power stations etc.;

- Supplementary tables of the database, such as monthly rate data on all hydrological stations of the river, characteristics of the water-storage reservoirs that are situated in the river headwaters, carrying capacity of the river, more detailed data about water intake from the river by type of water consumption (irrigation, grass cutting, ecological systems of swamp area, fishing industry, town and industrial water supply), irrigative regeneration flow, wastes and water loss, electricity production etc. 
Historical data about monthly river flow on each node point; monthly average data of evaporation on each water-storage reservoir and lake; characteristics of height and cubature on each water-storage reservoir and lake; steam consumption diagram of transformers on each hydro-electric power station; data about water withdrawal from the river on each node point were studied in the time of engineering the SICWR 2 (the system of integrated control of water resources).

According to our estimation these additions to the SICWR will cover the whole cascade of main regulation structures of the Syr-Darya river basin, which are situated in contiguous states and in Kazakhstan part of the basin (a total of 30 constructions). This will allow to engineer effectively and to accept coordinated actions on the level of governments of Central Asian republics and of the republic of Kazakhstan: estimation of expected water content and possible consequences, ways of risk reduction of overflow of the Shardara water-storage reservoir and emergency on the downgradient territories and reaching the main purpose of the project.

\subsection{The Hydraulic Simulation}

The hydraulic simulation of Kazakhstan part of the Syr-Darya river basin is based on division of the river into 9 waterwork parts, limited by node points (hydrological station or water control structures). Model experiment blocks include water-diverting structures of surface water and types of water consumption. The total cubature of water intake from the Syr-Darya River in the limits of Kazakhstan territory for sections is reflected in the tabular form.

Provision statistics visualize the Syr-Darya River modes at different variants of electricity production without and with building the Koksarai water body according to 7 main scripts. The existing (extreme mode of electricity production) and predicted (stable mode of electricity production) conditions of the Naryn-Syr-Darya chain of power plants come into account in this case. Simulation data of augmentation from the Shardara water-storage reservoir to the lower and discharges into the Arnasai low is reflected. Hydrologic balance provision on node points of model experiment sections is also calculated.

Calculation data, that are used on the Mike 11 software simulator by defining water levels of the Syr-Darya River in summer and winter period show rather good compatibility of actual data with actual measured levels, shown in the RSRNAS 1 project in summer time and notable excess (on average for about $1.5 \mathrm{~m}$ ) over these values in wintertime.

The final version of the calculation for "normal" winter is performed to decrease in value the flood-protection works.

The model of the RSRNAS 1 project applies the width of cross sections within 400 - $7000 \mathrm{~m}$, i.e. closer to the natural hydrogeological mode of the bottom-land, while the RSRNAS 2 project limits the bed width of the Syr-Darya River by the raised dams at the 150 - $4500 \mathrm{~m}$ limit. While engineering the protective dams' levels the RSRNAS 2 model gives higher data, than the RSRNAS 1.

Fixed charges of the Syr-Darya river-bed at the limits of $100-2000 \mathrm{~m}^{3} / \mathrm{s}$ in summertime, $100-1200 \mathrm{~m}^{3} / \mathrm{s} \mathrm{in}$ wintertime, and for the channel Karaozek-25 - $400 \mathrm{~m}^{3} / \mathrm{s}$ were used in the calculation.

By the estimation of the canal capacity of the Syr-Darya River in summer and winter period there were used two modules of the ice buildup hydrodynamics, taking into account a great number of dynamic processes. The influence of ice cover on the canal capacity taking into account the increased stream resistance that results in water level raising and flow velocity was well-defined. The individual model for the channel Karaozek including the calculation of two bridges was designed.

The carrying capacity in wintertime was estimated with the help of the quasistationary model experiment of the Mike 11 program with man-made assumption of side stream stability from the river headwaters. The quasistationary model experiment supposes growth of thickness and size of the ice cover till the definite rate and then its stabilization through the time to provide constant steady flow along the length of the river, and in connection with that the calculation is performed step-by-step in the "level-rate" form.

The model experiment of the service gates on Kyzylorda, Aitek, Kazalinsk, Aklak waterworks facilities in wintertime is realized with the help of Mike 11 program for standard flat sliding breechblock, in fully accessible position and relative thrashing, by decreasing calculated width of the water-gate.

It is estimated, that researches, conducted for size detection of augmentation from the Shardara water-storage reservoir in winter period till the end of building the Shardara waterworks facility, identified [3] [4] that dangerous phenomena in the river downstream in $62 \%$ happen because of ice out, in $32 \%$ when frost action and in $6 \%$ 
when freezing period and breaking up of peak levels of water to ice phases takes place in $82 \%$ because of ice out, in $6 \%$ when frost action and in $12 \%$ when freezing period.

The information about winter levels shown in hydraulic simulation refers to freezing period without differentiation of ice-out or freezing up, i.e. results of hydraulic modeling at this part do not reflect the real view of winter difficulties and floods on the Syr-Darya River.

\subsection{The Environmental Impact Statement}

The following projects are involved into the environmental impact statement:

- Package of the projects for river basin management;

- Motor-road bridges;

- Complex of constructions in the Saryshaganak cove.

The environmental impact statement in the RSRNAS 2 is given throughout all complexes of subprojects:

- Building of additional discharge sluice on the Shardara;

- Facilities construction for pass winter rate on the river Syr-Darya;

- Flood protective dam and drainage cut;

- Reconstruction of the left bank regulator of the Kyzylorda waterworks facility;

- Raising of water level in the Saryshaganak cove.

At that the main attention is paid to the following nature factors:

- Hydrological, hydrochemical, hydrogeological modes;

- Influence to atmospheric air;

- Impact to soil;

- Impact to biological diversity;

- Environmental action of man;

- Worse case script (dam and other. construction failure);

- Compatibility with other projects.

The RSRNAS 2 project will affect sizable zones of native habitat:

- Hydroeconomic zones of the Syr-Darya river, water areas of the Aral Sea, the natural lows Aidarkul-Arnasai, lake systems in estuary and many ecological and economical complex lower reaches;

- Riparian woodlands in the Syr-Darya flood bed, as important native habitat of the specific ecological system of Central Asian Rivers.

Qualitative evaluation of the level of effects on the environment in general is given (increase, decrease, not exert influence). But for the objective estimation of the priority of offered measures it is necessary to have quantitative estimation in the form of social, ecological and economic damage to environment or received effect.

Risks and impacts on affected area, which often are bigger than proximately project zone, must be estimated in the environmental impact estimation (OBOC).

The prevention methods of reducing and compensating negative environmental impact must be defined, as well as the potential measures for increasing positive influence on projected economic effect.

The environmental impact of the whole complex Koksarai has either negative or beneficial effect. The main drawbacks are:

- Waste of riparian woodland on square area of 1344 ha because of long-continued waterflooding in wintertime;

- further losses of water of the Syr-Darya river because of evaporation $0.282 \mathrm{~km}^{3}$;

- 48178 ha of native grassland, 350 ha of hayfield and 115 ha of flood arable land will be lost.

The environmental impact according to the RSRNAS 2 project conforms to the work policy of World Bank.

The researches conform to the requirements of legal system of Kazakhstan for the environment protection. The important statement in these laws is the fact that engineering design must conform to the international standards about environment protection and monitoring.

The completeness of usage of the information material for designing report about the environmental impact in spite of insufficient development of monitoring systems can be considered satisfactory.

\section{Water-Resources Management}

Water sources in this region are a primary factor in stabilization of the ecological and economic environment. 
The RSRNAS 2 project influences two trans-border objects-the NAS with the section of the Syr-Darya river below the Shardara water-storage reservoir and the system of the Shardara water-storage reservoir-the Aidarkul-Arnasai low, which is shared with the republic of Uzbekistan that suppose the solution of questions at the level of double-sided conference room processes.

In the years with abundance of water the cubature of discharges into Aidarkul-Arnasai low is $7.5 \mathrm{~km}^{3}$. In 1969 , a year with abundance of water about $20 \mathrm{~km}^{3}$ of water was discharged into this low forcedly. In 1991 square area of the lake was $232.0 \mathrm{~km}^{2}$. In June of 1998 year flooded area was $306.7 \mathrm{~km}^{2}$, and cubature of water was about $32.26 \mathrm{~km}^{3}$. Vast pasture-lands were lost. The government of Uzbekistan requested the government of Kazakhstan to stop the discharge, and this was taken into consideration. However, the primary purpose to prevent discharge into the Arnasai was not reached because of the remaining narrow spaces for flowing of the Syr-Darya river and refusal to realize coordinated operating regime in upstream water-storage reservoirs in wintertime.

Different variants of the alternative water body reservoir in winter hydroelectric flow were studied in the project. According to the project of discharges into the Arnasai may be decreased, but this does not entirely solve the problem of passing the flood with probability 1 time per 10,000 years. Energetic operating regime of the Toktagul water-storage reservoir results to water surplus in the river in wintertime, to ecological problems in downstream of the river and loss of the infrastructure, to lake system in the high-water bed. According to specialists solving the problem of decreasing discharge water in winter period and beginning to use it economical and with maximum efficiency, is possible only under mutually acceptable coordination of actions in water and others natural resources and division the responsibility between all concerned sides.

In prevailing conditions it is necessary to control water-energy resources of the basin below the Shardara water-storage reservoir, because its absence will possibly have negative social and economic consequences.

\section{Technical Solution on Reconstruction of Existing and Building up New Hydro Schemes and Constructions}

In the projects of the whole system of water control structures of the Syr-Darya river basin, developed in Soviet period, the Toktagul water-storage reservoir was created to operate in irrigative mode (priming of storage capacity in wintertime and flush through turbines of hydro-electric power stations in summertime for satisfacting irrigative consumers). The Arnasai deep with discharge sluice with carrying capacity $2300 \mathrm{~m}^{3} / \mathrm{s}$ was created as the waterflood storage capacity. The Shardara water-storage reservoir fulfilled regulating functions. Therefore, it is evident, that it is necessary to suggest as an alternative choice of water body to consider the possibility of increasing the storage capacity of the Shardara water-storage reservoir and to give social ecological and economic evaluation of this alternative choice, which is absent in the project.

Hydrologic researches detected, that the Shardara dam and the Arnasai dam can not securely pass the flood, which happens 1 time per 10,000 years, i.e. flood that is taken into account in ICOLD standard about stability of the dam. Maximum calculated flood is from 4650 till $5850 \mathrm{~m}^{3} / \mathrm{s}$. The existent discharge capability of the Shardara dam, even after reconstruction, runs to maximum $2000 \mathrm{~m}^{3} / \mathrm{s}$ (discharge sluice $1282 \mathrm{~m}^{3} / \mathrm{s}+$ turbine $518 \mathrm{~m}^{3} / \mathrm{s}$ + Kizilkumskiy discharge outlet $200 \mathrm{~m}^{3} / \mathrm{s}$ ). The discharge capability of Arnasai discharge sluice is reduced to $600 \mathrm{~m}^{3} / \mathrm{s}$, due to construction of cascade of dams in the Arnasai low in Uzbekistan. It blocks the discharge in the case of emergency. With relation to stability of the dam such situation is serious.

At the present time the cubature of flood water of 1969 (1 time per 50 years) can not be securely passed, without wish of contiguous states to destroy new Arnasai dams. The non-observance of the objectives of the World Bank in part of passing emergency floods through category "A" constructions takes place in this particular case.

In the time of maximum flood $3200 \mathrm{~m}^{3} / \mathrm{s}$ with degree of probability 1 time per 10,000 years social ecologic economic damage is measured as:

- $\quad$ potential loss of life of 392.5 thousand people living in the hazard area;

- economic damage is divided into material and nonmaterial, which can be rated as $10 \%$ from material (this is unreasonable presumption).

The best choice for the passing catastrophic flood for the present is reconstruction of carrying capacity into the Arnasai low. However, the realization of these measures is very problematic, and the flood hazard remains.

In the context of the global climate warming the square area and size of mountain glaciers that feed rivers is decreasing. The climatologists and hydrologists come to the conclusion about reducing cubature of river flow, 
but the degree of probability of maximum discharges will increase.

Among the technical solutions the problem of further water level increasing in the NAS has exceptionally environmental importance. The idea of raising water level in the Saryshaganak cove with the help of building a new dam before the baymouth and using water from the river Syr-Darya for priming created in such a way water body is not new. In the RSRNAS 2 project the reasoning of this component is studied in several variants:

1) New dam in the cove Saryshaganak for the cove priming only;

2) Building-up the existing NAS dam for priming the whole north-end of the Aral Sea;

3) Variant of water level mark afloat and-to-or in the cove: $45 \mathrm{~m}, 46 \mathrm{~m}$ and $47 \mathrm{~m}$ BS.

On the basis of comparison of the construction cost and presence of water sources for priming the cove the first variant was accepted, i.e. priming only the cove. As for the water level marks in the cove, the second variant was accepted, i.e. $46 \mathrm{~m} \mathrm{BS.}$

It is marked, that the complete recovery of water level in the NAS till the mark of about $50 \mathrm{~m}$ BS is impossible because of absence of enough fall from the planned water-diverting structure from the Syr-Darya river to the required distance and the risk of impossibility of reliable priming of the water body under available cubature of water, as the cubature of the water body is increasing itself.

The specified water level requires carrying out dredge operations at the depth of about 2 m to provide access for ships to the Aralsk port.

The offered technical solutions on raising of water level in the cove Saryshaganak has technical-and-economic calculations. However it is difficult to agree with some conclusions and design decisions.

In the first instance, the reconstruction of the cove Saryshaganak will decrease the cubature of water discharge into the Large Aral Sea by $1.5 \mathrm{~km}^{3}$, that will be used on waterflooding of the cove and about $0.5 \mathrm{~km}^{3}$ will get away as evaporation loss and filtration. The impact of these measures on the balance of the Large Aral Sea is prooflessly considered insignificant.

In the second place, the design decisions of the complex of construction in the Saryshaganak cove require the revision, i.e. some of its components (water level on the mark $46 \mathrm{~m} \mathrm{BS}$, water delivery canal that connect water body with the Aralsk town) can lead to serious negative environmental consequences.

1) The water level in the cove on the mark $46 \mathrm{~m}$ BS creates the water body with sizable square area of shallow waters with intensive development processes of eutrophication that leads to fish kill and increase the evaporation.

2) It is impossible to control the process of desalination in the cove, i.e. this process in the project is not estimated in time and depends on the depth and the cubature of water in the water body. According to the data of Kazakh Research Institute of Water Management LTD (August 2008) the mineralization of water in the cove on the mark $42 \mathrm{~m} \mathrm{BS}$ at the average depth $0.5 \mathrm{~m}$ and cubature 100 million $\mathrm{m}^{3}$ was $34 \mathrm{~g} / \mathrm{l}$, and the salt content of the surface soil in the central part of the cove ranged up to $6 \mathrm{~g} / \mathrm{l}$.

3) The water delivery canal that connects the water body with the port terminal in the town Aralsk is not flowing, therefore it will be covered with sand during dust-storms in the Priaralsk as the sands of the Aralkum from south-east are close to it.

4) The refusal from the level $50 \mathrm{~m}$ BS is reasoned with the absence of the fall from the Syr-Darya river till the cove and a high cost of building-up the mark of the dam till $52.4 \mathrm{~m}$ BS. The alternative choices of water delivery into the cove were not studied in the project and the variant of water extraction from the river higher than the waterworks facility Aklak with the calculated mark of the bottom $48.02 \mathrm{~m}$ was accepted. Meanwhile, the variants of water intake and water transmission till the cove by water delivery canals from the Raim dam sit or the Kazalinsk waterworks facility with the delivery into the cove on the mark $50 \mathrm{~m}$ BS were not studied.

At the present time design engineers explain the refusal from the level of $50 \mathrm{~m}$ BS because of deficiency of water sources for keeping up water level in the cove at this mark. The calculations proved the inefficiency of this argument. The hydrographic characteristics of the NAS and the Saryshaganak cove are shown in Figure 1 and Figure 2.

These graphics show that for priming the NAS till the mark $50 \mathrm{~m}$ BS it is necessary $56-57 \mathrm{~km}^{3}$ of water, and till the mark $46 \mathrm{~m} \mathrm{BS}-41 \mathrm{~km}^{3}$, nowadays the cubature of the NAS at the mark $42 \mathrm{~m} \mathrm{BS}$ is $27 \mathrm{~km}^{3}$ i.e. the additional cubature is 30 and $14 \mathrm{~km}^{3}$, at a year-round inflow it is necessary to deliver accordingly 951 and 443 $\mathrm{m}^{3} / \mathrm{sec}$ of water. This increases the rate by $25 \%$ - $30 \%$ without taking into account the evaporation losses. Kazakhstan does not have enough resources in lower reaches of the Syr-Darya River.

As for priming of the Saryshyganak cove the deal is more satisfactory. Cove priming at marks 46 and $50 \mathrm{~m}$ 


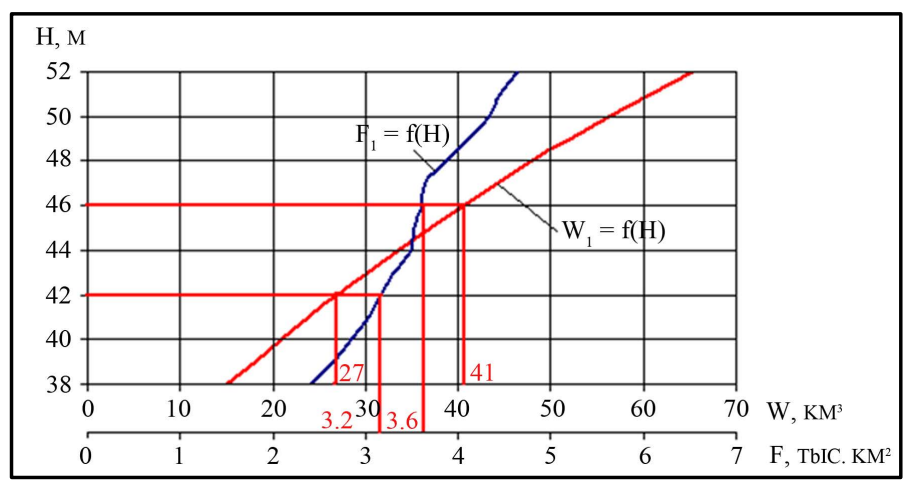

Figure 1. The hydrographic characteristic of NAS.

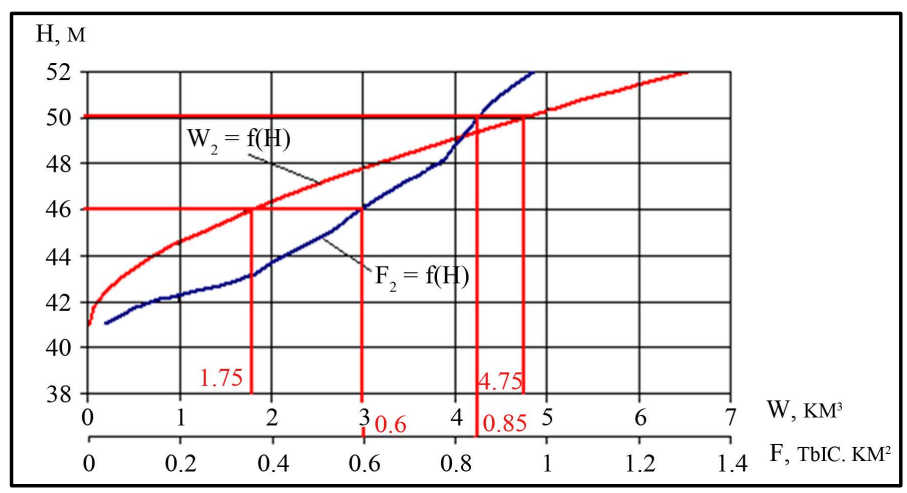

Figure 2. The hydrographic characteristic of the Saryshaganak cove.

BS will demand $1.75 \mathrm{~km}^{3}$ and $4.75 \mathrm{~km}^{3}$ of water, that comprise 55 and $150 \mathrm{~m} / \mathrm{s}$, with allowance for evaporation loss the flow requirement can reach 70 and $195 \mathrm{~m}^{3} / \mathrm{s}$. Such amount of water may be broken free for filling of the Saryshyganak cove, taking into account the design conditions of the Aklak hydro-electric power station.

The question concerning water delivery into the Saryshyganak cove was also investigated by specialists of the Kazakh Research Institute of Water Management LTD, who offered two variants of canal route that directly delivers the water into the cove near the Aralsk town (look at the separate picture). In this variant, besides the removal of other disadvantages of the design choices, there will be an opportunity to create a recreation zone in the Aralsk town that had never been before, that will result the appearance of the clean river water on the territory of the city, as it had been till 1970.

\section{Conclusions}

At the stage of state expert examination specialists of the Kazakh Research Institute of Water Management LTD and the Taraz State University named after M. Dulati pointed out marked disadvantages [2]. That was also marked in the letters to ex-Minister of Agriculture of Kazakhstan A.S. Esimov No. 02-03/291 d.d. 28.06.2007, to the Committee of Water Resource of the Ministry of Agriculture of RK No. 01-09/290 d.d. 28.06.2007, etc. In these letters, we proved the necessity of reaching of the cove level till $50 \mathrm{~m}$ BS and pointed out the ways of its achievement, that were described above.

In conclusion, we'll mark that the water level in the Saryshaganak cove must reach $50 \mathrm{~m}$ BS that provides well ecological and favorable regime in the project zone.

\section{References}

[1] (2008) Regulation Project of the Syr-Darya Bed and the North Part of the Aral Sea, Phase-II. TER (Technical Economical Reasoning). Summary Report, Vols. 1-5, Consortium of Companies: Euroconsult-Mott MacDonald, JacobsBabtie, Danish Hydraulic Institute, Kazgiprovodhoz Institute.

[2] (2008) Expert Evaluation of “Technical and Economic Assessment of Regulation Project of the Syr-Darya Bed and 
North Part of Aral Sea Project”. Phase II, Taraz, 32.

[3] Mashukov, P.M. (1969) Hydrometeorological Conditions of Winter Floods on the Syr-Darya. Leningrad, 139.

[4] Karlykhanov, O.K., Balgerei, M.A., Ibraev, T.T. and Badjanov, B.M. (2008) Modern Syr-Darya: Problems, Reasons, Ways of Solution. Taraz, 170. 
Scientific Research Publishing (SCIRP) is one of the largest Open Access journal publishers. It is currently publishing more than 200 open access, online, peer-reviewed journals covering a wide range of academic disciplines. SCIRP serves the worldwide academic communities and contributes to the progress and application of science with its publication.

Other selected journals from SCIRP are listed as below. Submit your manuscript to us via either submit@scirp.org or Online Submission Portal.
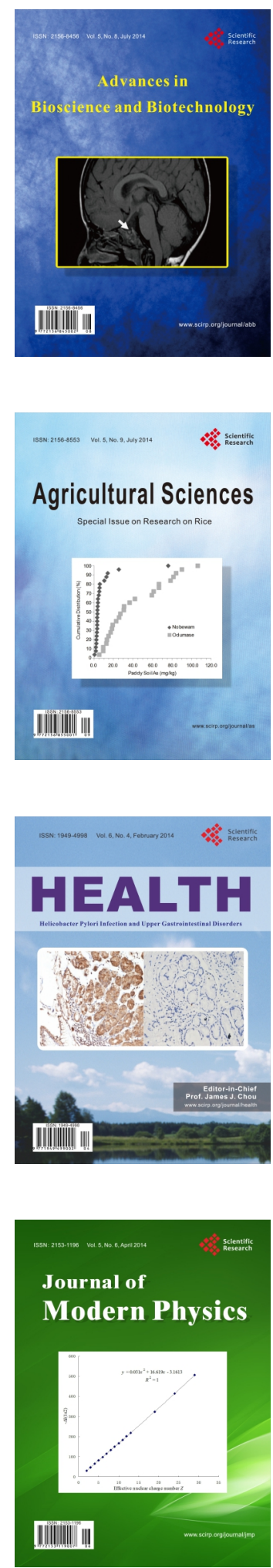
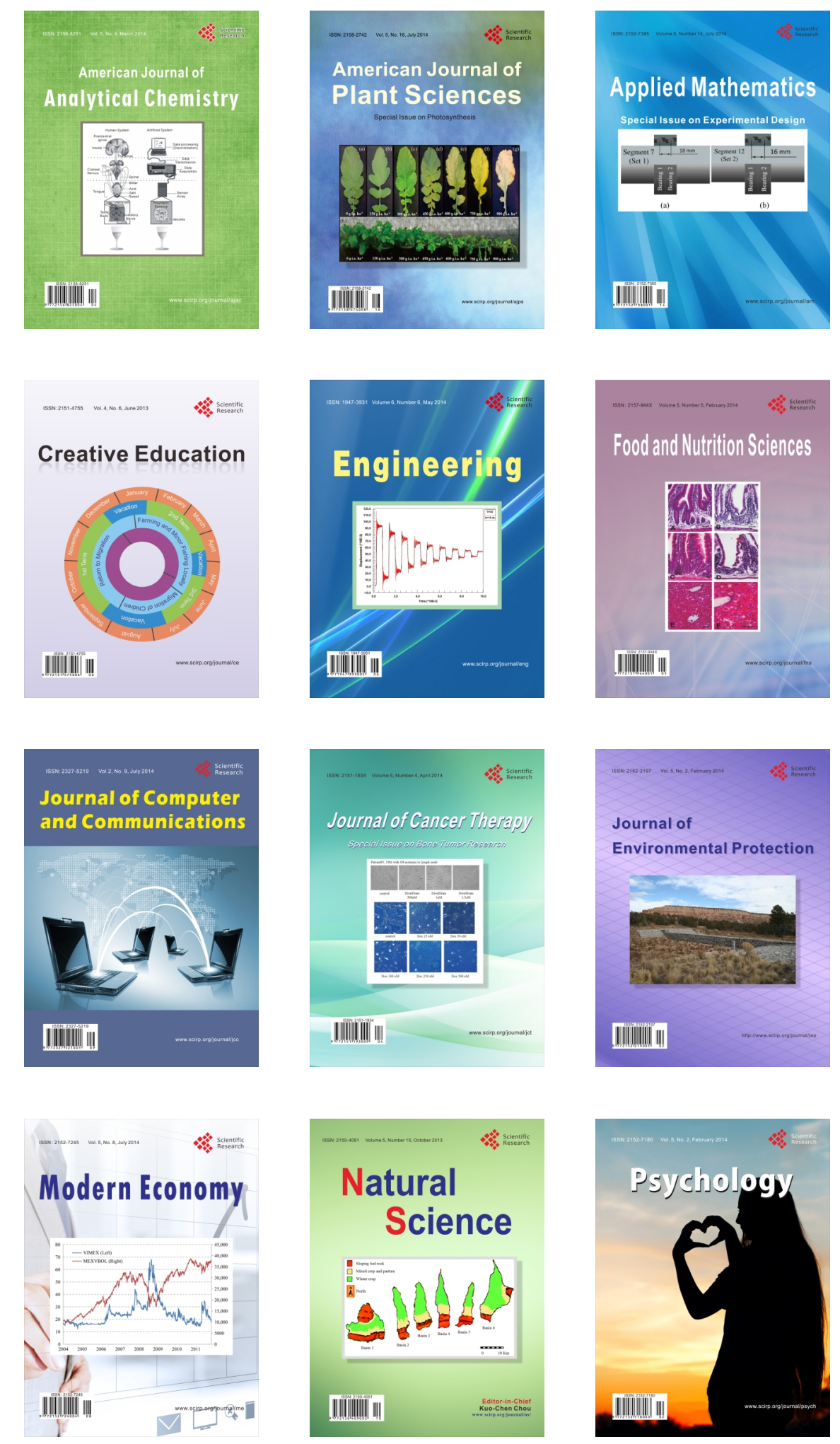